\title{
6 年制実務実習指導体制構築におけるグループワークの有用性
}

\author{
久保和子, ${ }^{a}$ 岡崎宏美, ${ }^{a}$ 市川裕規, ${ }^{a}$ 西原茂樹, ${ }^{a}$ 名和秀起, ${ }^{a}$ \\ 岡崎昌利, ${ }^{a}$ 河崎陽一, ${ }^{a}$ 名倉弘哲, ${ }^{b}$ 松永 $\quad$ 尚, ${ }^{a}$ 千堂年昭 $*, a$
}

\section{Usefulness of Group Work as a Teaching Strategy for Long-Term Practical Training in the 6-Year Pharmaceutical Education}

\author{
Kazuko Kubo, ${ }^{a}$ Hiromi Okazaki, ${ }^{a}$ Hiroki Ichikawa, ${ }^{a}$ Shigeki Nishihara, ${ }^{a}$ \\ Hideki Nawa, ${ }^{a}$ Masatoshi Okazaki, ${ }^{a}$ Yoichi Kawasaki, ${ }^{a}$ Hironori Nakura, ${ }^{b}$ \\ Hisashi Matsunaga, ${ }^{a}$ and Toshiaki Sendo*,a \\ ${ }^{a}$ Department of Hospital Pharmacy, Okayama University Hospital; and ${ }^{b}$ Okayama University Center for the \\ Development of Medical and Health Care Education Graduate School of Medicine, Dentistry \\ and Pharmaceutical Sciences; 2-5-1 Shikata-cho, Kita-ku, Okayama 700-8558, Japan.
}

(Received February 10, 2012; Accepted August 23, 2012; Advance publication released online September 18; 2012)

\begin{abstract}
At the initiation of long-term practical training in the 6-year pharmaceutical education, there are many issues to be solved. For example, it is necessary for teaching pharmacists, who are in charge of both staffing and teaching pharmacy students, to manage their workload with other staff pharmacists. To overcome this situation and to improve the motivation of teaching pharmacists towards student practical training, we twice held group work (GW) sessions for teaching pharmacists, and then evaluated whether such training was effective for their understanding of the Model Core Curriculum for Practical Training and for promoting a higher level of motivation. During the two-day GW discussions, teaching pharmacists, who work daily in the dispensing area, were separated into two groups to discuss teaching skills. A questionnaire survey was completed by participants before and after each GW session. According to the survey, more than $90 \%$ of the pharmacists had a higher motivation level for practical training after the sessions. Particularly in the second GW training, the response rate of "being actively involved" improved from $40 \%$ to $70 \%$. Furthermore, "The Educational Evaluation Testing" was conducted, which confirmed the increased participant comprehension. The median scores of the comprehensive exams significantly $(p<0.01)$ improved in twice GW, respectively. Therefore, we conclude that GW sessions are a useful tool for both improving professional knowledge about the Model Core Curriculum and motivating teaching pharmacists involved in the practical training of students. We hope that this exercise will lead to higher student motivation and satisfaction during their practical training.
\end{abstract}

Key words - long-term practical training; group work; motivation; Model Core Curriculum for Practical Training; teaching pharmacist

\section{緒言}

薬学教育 6 年制における長期実務実習では, 人員 不足や通常業務との両立における指導者への負担な どの問題解決が急務とされている. ${ }^{1)}$ 臨床実習を有 意義な内容にするための研究において，奥宮ら ${ }^{2}$ は 医学部学生の満足度と, 責任者の熱意や指導者の熱 意に有意な相関がみられることを報告している。こ

The authors declare no conflict of interest.

$a$ 岡山大学病院薬剤部, $b$ 岡山大学医療教育統合開発セ ンター

*e-mail: sendou@md.okayama-u.ac.jp
のことは, 指導者の熱意を向上させることが, 学生 の高い満足度につながることを示唆している。ま た，指導者のモチベーションを向上させることがで きれば，熱意ある指導につながると考える，一方， 実務実習の質を担保するためには, 指導薬剤師の資 質や実習の成果が客観的に評価されることが重要で ある. ${ }^{3)}$ すなわち, 学生の満足度は, 客観的評価の 指標の 1 つになると考えられ，学生の満足度を高め るための取り組みも必要である.

実務実習モデル・コアカリキュラム（以下，コア カリと略す）に基づく参加型実習を，均一でより質 の高いものにするためには，認定実務実習指導薬剤 
師（以下，指導薬剂師と略す）以外の薬剤師の協力 が必須であり，そのための人材を育成することが必 要である. 山本ら ${ }^{4)}$ は，大学院生を対象とした施設 内グループ実習のトライアルを行うにあたり，事前 に職員教育を実施した成果を報告している。しかし， 6 年制の実務実習に直接適用する目的で，カリキュ ラムプランニングを中心テーマとした職員教育を行 い，職員個々のコアカリの理解や実習指導に対する モチベーションの変化を検討した報告はない.

そこで今回，6 年制実務実習受け入れに向けた事 前準備として, 実務経験の浅い薬剤師が多く，かつ コアカリの該当到達目標（specific behavioral objectives; SBOs）の多い部署である調剤室配属の薬剤師 を対象に，コアカリのよりよい理解と実習指導への モチベーションの向上を目的に，グループワークを 主体とする研修会（以下，GW と略す）を開催し， その有用性を検討したので報告する.

\section{方法}

1. $\mathbf{G W}$ の実施方法及び対象者 第 1 回 $\mathrm{GW}$ は，調剤室配属の薬剤師 11 名を対象とした。指導 薬剂師がタスクフォースとなり，認定実務実習指導 薬剤師養成ワークショップ（以下，WS と略す）の 内容を一部導入した方法で，平成 22 年 2 月 10 日, 2 月 16 日にレクチャー及びスモールグループディ スカション（small group discussion; SGD）をそれ ぞれ約 2 時間開催した。タイムスケジュールは Fig. 1 に示す.

まず「薬学教育 6 年制における実習開始に向けて」 と題し, 実務経験の浅い薬剤師であっても, 実習に 対する不安を少しでも解消し，積極的に実習指導に 係わることができるよう，実習指導に対する望まし い指導方針についてレクチャーを行つた．次に，指 導薬剤師以外の薬剤師も, コアカリについて理解し た上で実習指導に係わることができるよう，カリキ ユラムの三要素である目標・方略・評価に関するレ クチャーを 2 日間に分けて段階的に行った.

SGD は，実務経験年数，年齢を基に，グループ のバランスがほぼ同等になるよう，参加者を 2 グ ループ（A-1グループ：5名， B-1 グループ：6 名） に分けて行った。テーマは，「調剤室での実習の問 題点」, 「調剤室の実習スケジュール作成」とし, 各 SGD 後に, 各グループのプロダクト発表と総合討
論を行った，問題点の抽出は，司会者，記録係，発 表者をそれぞれ 1 名決めて，ホワイトボードに列挙 した. 2 グループから抽出された問題点を分類し， 問題点に対する現状を踏まえたうえで，調剤室担当 の SBOs 30 項目について, 学生 4-5 名 (2-3 名 $\times 2$ グループ）を想定した 2 週間の実習スケジュールの 作成に取り組んだ.

第 2 回 $\mathrm{GW}$ は，平成 22 年 4 月以降に調剂室に配 属された新採用薬剤師 10 名を対象に，平成 22 年 4 月 22 日，5月 7 日に開催した。タイムスケジュー ルは第 1 回 GW とほぼ同様の内容で行った。 SGD のグループ分けは，第 1 回 $\mathrm{GW}$ とは異なり，実習 指導体制を考えるうえで，指導者側の視点だけでな く, 学生側の視点からも議論し易いように, 年齢と 経歴から，A-2 グループ（実務経験者 5 名）と B-2 グループ（新卒者のみ 5 名）とした。また，「調剤 室の実習スケジュール作成」をテーマとした SGD では，各 SBO に対する学習方略作成の作業手順を 明確にし，限られた時間で効率よく議論を進める目 的で，タスクフォースが作成したモデル案を例示 し，スケジュール表を作成した。 なお，モデル案は， GW の参加者が異なっても，繰り返し議論するこ とにより，効果的かつ実現可能なスケジュールに仕 上げるため，第 1 回 $\mathrm{GW}$ で作成されたスケジュー ル案を用いて作成した。ささらに，第 1 回 GW での 議論内容を根拠に基づき有効活用し易いように，第 1 回 GW 参加者を各グループに 1 名ずつ議論に参 加できる立場で配置した。

2. GW 開催の有用性の検討 第 1 回, 第 2 回 GW において，以下の方法で有用性を検討した.

2-1. アンケートの実施参加者の背景の把握 と実習指導へのモチベーションの変化を確認するた め， GW 前後にアンケートを実施した。 その内容 を Fig. 2 に示す.

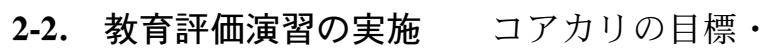
方略・評価に関する知識の習得度を確認するため, 2 日間のレクチャーの前後で「教育評価演習」（Fig. 3）を実施した。設問は，日本医学教育学会監修 『医療プロフェッショナルワークショップガイド』 （篠原出版新社）を参考に作成し，解答例に従い 1 問 1 点として得点を前後で比較した.

2-3. 自己評価の実施 1 日の「振り返り」に よる参加者自身の評価や意見を把握することにより， 
第 1 回 調剤室 GW タイムスケジュール

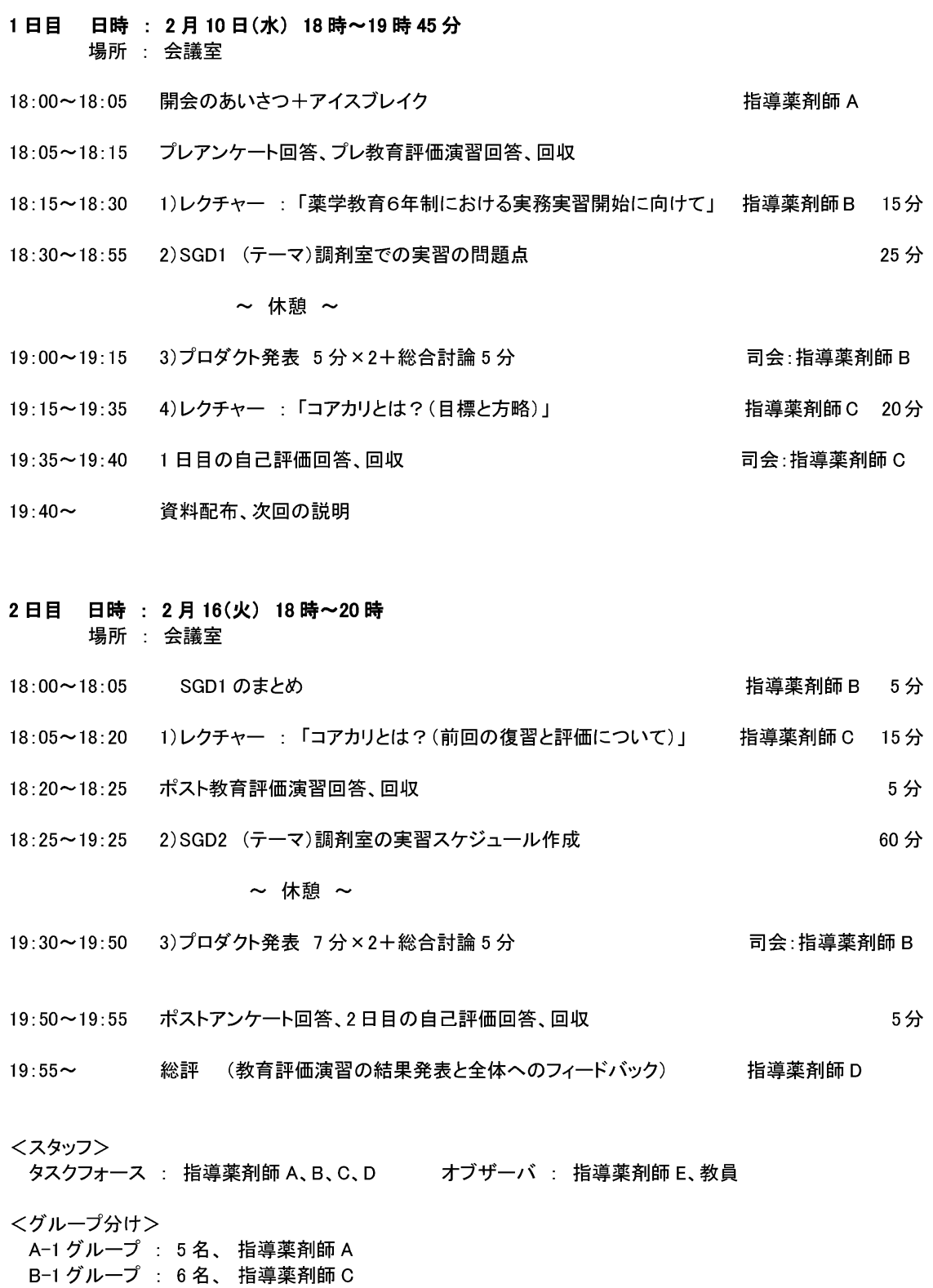

Fig. 1. Time Schedule for the First Group Work

GW の有用性を開催内容毎に検討するため, 各開 催日の終了時に自己評価を実施した。内容は，問 1：「今日，あなたは討議にどの程度参加しました か?」, 問 2:「今日の内容は，あなたの期待に応え ることができましたか?」，問 3：「今日，あなたに とつて価値ある変化がありましたか?!に対する 5 段階評価（1 無 $\rightarrow 5$ 有）とし，問 4 ：「今日，よく理 解できたこと」, 問 5 :「今日, よく理解できなかっ
たこと」及び，「その他の意見・感想」については 記述式とした。

3. 統計処理 教育評価演習及び自己評価の データは, Wilcoxon 順位和検定を用いて解析し た. また, 危険率 $p<0.05$ で有意差ありと判定した.

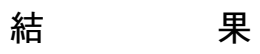

1.SGD の結果 第 1 回 GW では, 調剤室で 


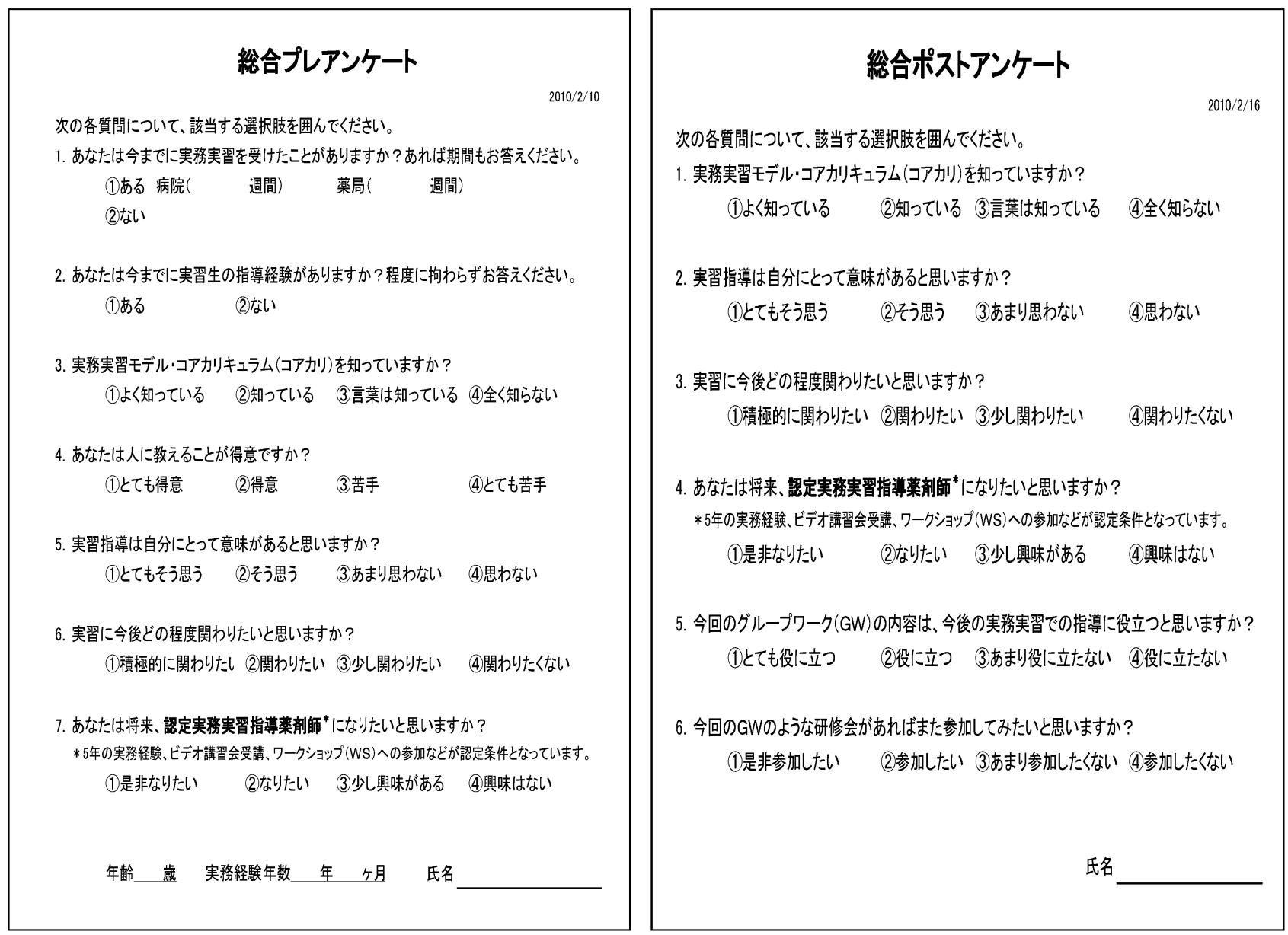

Fig. 2. Questionnaire Survey before and after the Group Work

の実習の問題点について討論を行つた結果， 15 個 の問題点が抽出され，既に解決策がある程度見えて いる問題点と，これから解決策を考えなければいけ ない問題点に分類することができた（Table 1).

第 2 回 GW における実習スケジュール作成で は，タスクフォースがモデル案を例示し，作業手順 を明確にしてスケジュール作成に取り組んだ結果, 実習順序や必要な資源, 評価方法も検討することで 2 週間の実習スケジュール（Table 2) を完成する ことができた．各グループ 1 名ずつ第 1 回 GW 参 加者を配置したことも，議論の円滑な進行に役立つ た.

\section{GW 開催の有用性}

2-1. アンケート結果 $\quad \mathrm{GW}$ 開始時に行ったプ レアンケートは，回収率 100\%であった，対象者の 背景を Table 3 に示す。問 4 ：「あなたは人に教え ることが得意ですか?」に対し，第 1 回 GW では 「得意」 $27 \%$ ，「苦手」55\%，「とても苦手」 $18 \%$ ，
第 2 回 GW では「得意」 $40 \%$,「苦手」60\%であつ た.

2 日間の $\mathrm{GW}$ 終了時に行ったポストアンケート は，回収率 100\%であった。プレとポストで同一の 質問を行い，比較した結果を Fig. 4 に示す。プレ アンケートの段階では，コアカリを「知っている」 と答えた参加者は，第 1 回 GW18\%，第 2 回 GW50\%であったが，GW 後では，それぞれ 91\%， 90\%の参加者が「知っている」と回答した.

2-2. 教育評価演習の結果 レクチャーの前後 で実施した教育評価演習の結果，得点の中央值は第 1 回 $\mathrm{GW}$ では 4.0 点から 9.0 点へ，第 2 回 $\mathrm{GW}$ では 3.5 点から 8.0 点へ, 有意に $(p<0.01)$ 上昇した [Fig. 5(A) ]。また，実務経験年数 1 年未満（新卒 者，10 名）と 1 年以上（既卒者， 11 名）の 2 群に 分けて比較した結果，両群ともにプレとポストの得 点は有意に $(p<0.01)$ 上昇した $[\mathrm{Fig} .5(\mathrm{~B})]$.さ らに，2 群間のプレ及びポストの得点の中央值は同 
值であつた [Fig. 5(C)].

2-3. 自己評価の結果 1 日毎に 5 段階の自己 評価を行い, 最低を 1 , 最高を 5 として，1 日目と 2 日目のスコアの中央値を比較した（Fig. 6）。問 1

\section{教育評価演習}

次の各項目について、右欄の賛成、どちらともいえない、反対のいずれかにチェックノして ください。

\begin{tabular}{|c|c|c|c|}
\hline & 賛成 & 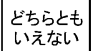 & 反対 \\
\hline \multicolumn{4}{|l|}{ 1. カリキュラムとは、学科別時間配分表のことである。 } \\
\hline \multicolumn{4}{|l|}{$\begin{array}{l}\text { 2. 学習目標は、教員(指導者)が何をすべきかを規定し } \\
\text { たものである。 }\end{array}$} \\
\hline \multicolumn{4}{|l|}{$\begin{array}{l}\text { 3. 学習目標として個別行動目標を設定することは、教育 } \\
\text { 活動を淛するのでよくない。 }\end{array}$} \\
\hline \multicolumn{4}{|l|}{ 4. 学習目標を設定しなくても、正しい評価は可能である。 } \\
\hline \multicolumn{4}{|l|}{$\begin{array}{l}\text { 5. 実習に際して、事前に関連する知識を十分に教えてお } \\
\text { くこがないととてある。 } \\
\end{array}$} \\
\hline \multicolumn{4}{|l|}{ 6. 学習には順次性が大切である。 } \\
\hline \multicolumn{4}{|l|}{ 7. 技能の評価は、口頭試験で行なうことができる。 } \\
\hline \multicolumn{4}{|l|}{$\begin{array}{l}\text { 8. 総括的評価は、学習者の知識、技能、態度を総合した } \\
\text { 評価のことである。 }\end{array}$} \\
\hline \multicolumn{4}{|l|}{ 9. 形成的評価は、進級のよい基準となる。 } \\
\hline \multicolumn{4}{|l|}{$\begin{array}{l}\text { 10. 観察記録は、観察したことを学習者が記録したもので } \\
\text { ある。 }\end{array}$} \\
\hline 氏名 & & & \\
\hline
\end{tabular}

Fig. 3. Educational Evaluation Testing
実務実習モデル・コアカリキュラムを知っていますか？

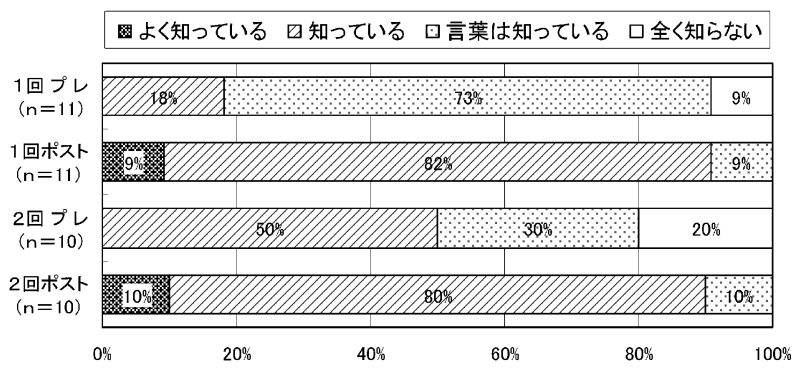

実習指導は、自分にとって意味があると思いますか？

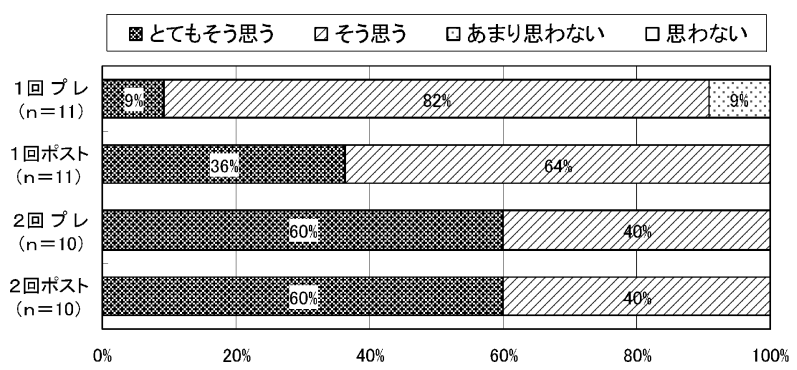

実習に、今後どの程度関わりたいと思いますか?

因積極的に関わりたい ロ関わりたい す少し関わりたい ロ関わりたくない

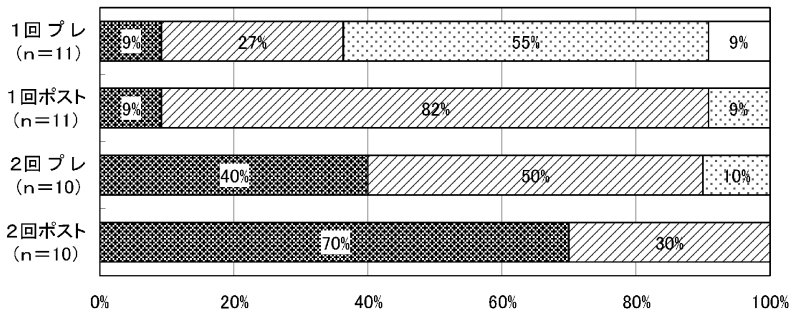

Fig. 4. Answers to the Questionnaire Survey before and after the Group Work

Table 1. Problems of Dispensing Practice, Which Discussed in the First Group Working

\begin{tabular}{|c|c|c|}
\hline \multicolumn{2}{|c|}{ 既に解決策が，ある程度見えている問題点 } & これから, 解決策を考えなければいけない \\
\hline 問 題 点 & 解 決 策 & 問 題 点 \\
\hline $\begin{array}{l}\text { 麻薬はどこまで実習するのか？ } \\
\text { 触る？見せる? }\end{array}$ & 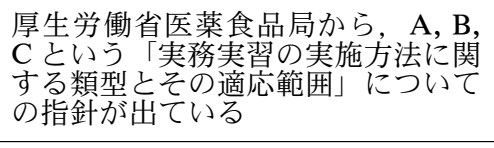 & \multirow{3}{*}{$\begin{array}{l}\text { 指導者側 } \\
\text { ・時間がない（人数が不足している） } \\
\text { ・指導する内容にバラツキがある（処方内容, 経 } \\
\text { 験年数, 経した施設など） } \\
\quad \text { 〈解決策案〉 } \\
\quad \text { 指導者を決める? 項目毎に担当制？ } \\
\text { ・どこまで教えるのか? 教える基準は? } \\
\text { ・教えているときのハプニングへの対応は? } \\
\text { ・調剂室内に十分なスペースがない }\end{array}$} \\
\hline 指導薬剂師の準備は？ & $\begin{array}{l}\text { ビデオ講習会, ワークショプ, この } \\
\text { 研修会 }\end{array}$ & \\
\hline 大学教員との話し合いの場が必要 & 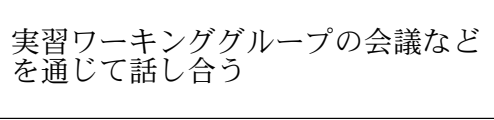 & \\
\hline $\begin{array}{l}\text { 学生との接し方（ハラスメントの防 } \\
\text { 止） }\end{array}$ & $\begin{array}{l}\text { ハラスメント講習会, 問題となった } \\
\text { 事例集等の活用 }\end{array}$ & \multirow{2}{*}{$\begin{array}{l}\text { 学生側 } \\
\text { ・学生の能力やモチベーションに差がある } \\
\text { ・ ゙こまで学生の知識があるのかわからない } \\
\text { ・1 つの処方を考える時間が少ない } \\
\text { ・(指導者に対し) 忙しそうで申し訳なく感じる } \\
\text { ・空き時間の使い方がわからない }\end{array}$} \\
\hline $\begin{array}{l}\text { 実習生のモチベーションに不安があ } \\
\text { る゙習生によってモチベーション } \\
\text { が異なる }\end{array}$ & 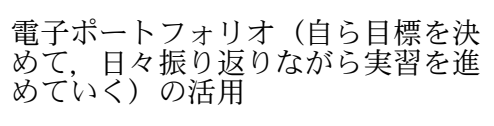 & \\
\hline
\end{tabular}


調剂室実習スケジュール表（I 期 5/17-5/28）

Table 2. Program in Dispensing Area

\begin{tabular}{|c|c|c|c|c|c|}
\hline & 5 月 17 日（月） & 5 月 18 日（火） & 5月 19 日（水） & 5 月 20 日（木） & 5 月 21 日（金） \\
\hline 随時 & \begin{tabular}{|l} 
议安全対策 $\quad$ H126-44, 45 \\
・ポケット版へミスを記入 \\
・インシデントレポート記入
\end{tabular} & $\begin{array}{c}\text { 出覚えておきたい医薬品一覽 } \\
\text { ）学習の成果を e-learnin } \\
\text { H107-15, 18, } 19 \text { H126-45 }\end{array}$ & $\begin{array}{l}\text { （実習時間の睱を見つけて） } \\
\text { gg でチェック（16 時以降に） }\end{array}$ & $\begin{array}{c}\text { 计疑義照会見学↔システ簡単な実例も } \\
\text { H105-11 H104-9, } \\
\text { H }\end{array}$ & $\begin{array}{l}\text { 败麻薬調剤・交付の見学 } \\
\text { H205-9, 10, } 12 \\
\text { H108-20 }\end{array}$ \\
\hline 12:00 & 全体オリエンテーション & 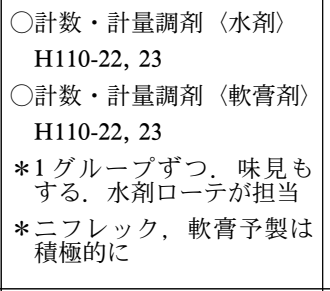 & 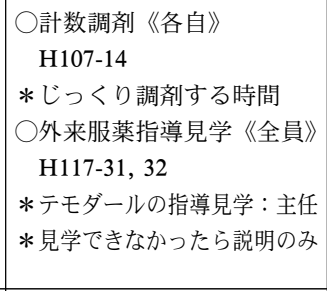 & \begin{tabular}{|l} 
計数・計量調剤〈粉砕〉 \\
$\mathrm{H} 112-26$ \\
○細胞毒性 \\
$\mathrm{H} 111-24,25$ \\
$* 1$ グループずつ \\
*乳糖をパッカーで手分包 \\
*1 人が分包している間に \\
交代で味見 \\
\end{tabular} & 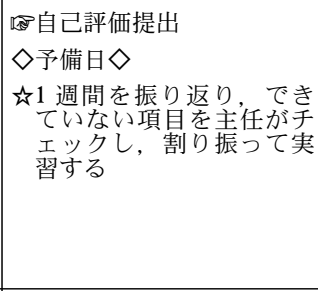 \\
\hline 12:00 & 昼休憩 & 昼休憩 & 昼休憩 & 昼休憩 & 昼休䭒 \\
\hline 13:00 & 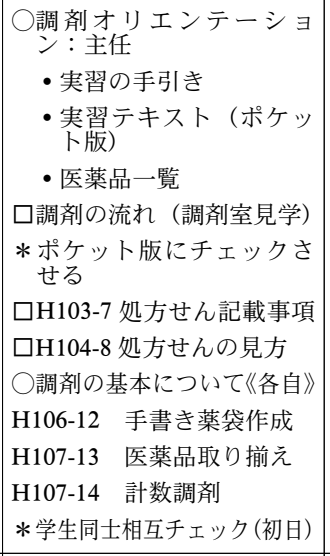 & $\begin{array}{l}\text { ○一包化調剤 } \\
\mathrm{H} 109-21 \\
\mathrm{H} 107-16,17 \\
* 1 \text { グルーブずつ } \\
\text { * Step 1 : 調剤シートで識別 } \\
\text { * Step 2: シートなしで識別 }\end{array}$ & $\begin{array}{l}\text { O計数・計量調剤〈散剂〉 } \\
\mathrm{H} 110-22,23 \\
\text { *1 グループずつ. 分包も } \\
\text { *散剤上ローテが指導 }\end{array}$ & 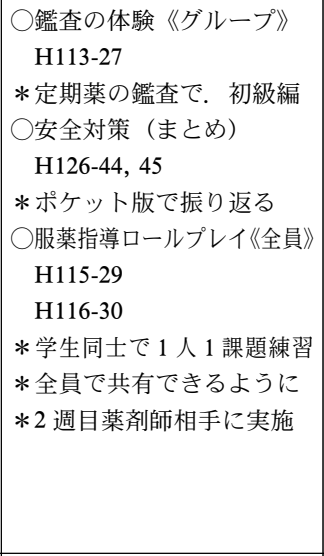 & \begin{tabular}{|} 
○インスリン自己注射の手技 \\
H116-30 \\
随時項目
\end{tabular} \\
\hline $17: 00$ & まとめの時間 & まとめの時間 & まとめの時間 & $\begin{array}{l}\text { 然自己評価記入 } \\
\text { まとめの時間 }\end{array}$ & \\
\hline \multicolumn{6}{|c|}{2 週目 : 1 週目の体験をもとに, より実践的に実習を行う. } \\
\hline & 5 月 24 日（月） & 5 月 25 日 (火) & 5 月 26 日 (水) & 5 月 27 日 (木) & 5月 28 日（金） \\
\hline 随時 & \begin{tabular}{|c|} 
安全対策 $\quad$ H126-44, 45 \\
・ポケット版へミスを記入 \\
・インシデントレポート記入
\end{tabular} & $\begin{array}{c}\text { 々覚えておきたい医薬品一覽 } \\
\quad \rightarrow \text { 学習の成果を e-learnin } \\
\text { H107-15, 18, } 19 \text { H126-45 }\end{array}$ & $\begin{array}{l}\text { (実習時間の暇を見つけて) } \\
\lg \text { でチェック（16 時以降に） }\end{array}$ & 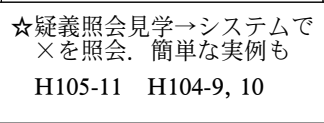 & $\begin{array}{l}\text { 麻薬調剤・交付の見学 } \\
\text { H205-9, 10, } 12 \\
\text { H108-20 }\end{array}$ \\
\hline \multirow[t]{2}{*}{ 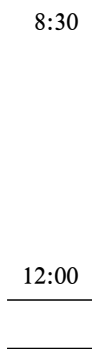 } & 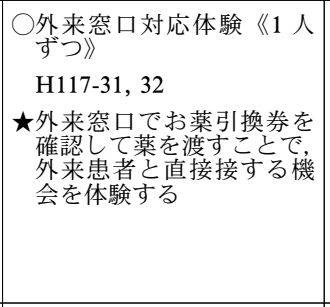 & 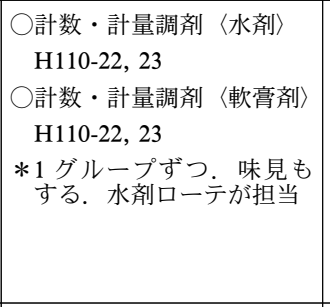 & \begin{tabular}{|l|} 
計数調剂《各自》 \\
H107-14 \\
○外来服薬指導見学《全員》 \\
H1117-31, 32 \\
$*$ テモダールの指導見学 : 主任 \\
$*$ 見学できなかったら説明のみ \\
○がん専門薬剂師のレクチャー
\end{tabular} & \begin{tabular}{|l|} 
計数・計量調剤〈粉砕〉 \\
H112-26 \\
O細胞毒性 \\
H111-24, 25 \\
$* 1$ グループずつ \\
$*$ 乳糖をパッカーで分包 \\
$* 1$ 人が分包している間に味見 \\
$(1$ 週目にできていれば省略 $)$
\end{tabular} & 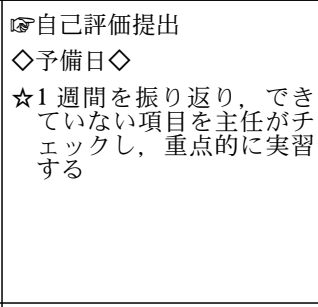 \\
\hline & 昼休憩 & 昼休頽 & 昼休憩 & 昼休頽 & 亘休嘼 \\
\hline 13:00 & 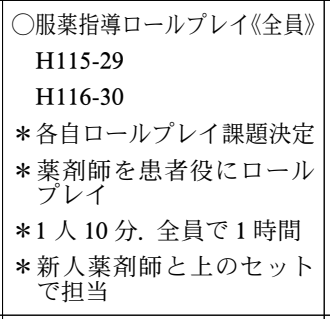 & \begin{tabular}{|l} 
○一包化調剤 \\
H109-21 \\
H107-16, 17 \\
$* 1$ グループずつ. \\
*Step 1 : 調剤シートで識別 \\
*Step 2: シートなしで識別 \\
认識別をポケット版へ記載
\end{tabular} & $\begin{array}{l}\text { O計数・計量調剤〈散剂〉 } \\
\text { H110-22, } 23 \\
* 1 \text { グループずつ. 分包も } \\
\text { * 散剤上ローテが指導 }\end{array}$ & 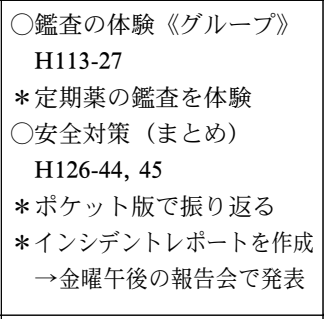 & \\
\hline 17:00 & まとめの時間 & まとめの時間 & まとめの時間 & $\begin{array}{l}\text { 自己評価記入 } \\
\text { まとめの時間 }\end{array}$ & 周 \\
\hline
\end{tabular}

スケジュールは目安です，五感を働かせて積極的に現場でしかできない体験をしてみましょう.

実習期間を通して,「覚えておきたい医薬品一覧」に取り組みながら，臨床に役立つ知識を身に付けていきましょう． 
Table 3. Background of the Participants

\begin{tabular}{|c|c|c|c|c|}
\hline & \multicolumn{2}{|c|}{ 第 1 回 GW } & \multicolumn{2}{|c|}{ 第 2 回 GW } \\
\hline & グループ & グループ & グループ & グループ \\
\hline $\begin{array}{l}\text { 平均実務経験 } \\
\text { 年数 (月) }\end{array}$ & $30.4 \pm 37.2$ & $38.1 \pm 30.9$ & $60.4 \pm 55.9$ & $1.0 \pm 0.0$ \\
\hline 平均年齢 (歳) & $26.4 \pm 4.0$ & $29.6 \pm 6.6$ & $31.8 \pm 3.1$ & $24.2 \pm 0.4$ \\
\hline
\end{tabular}
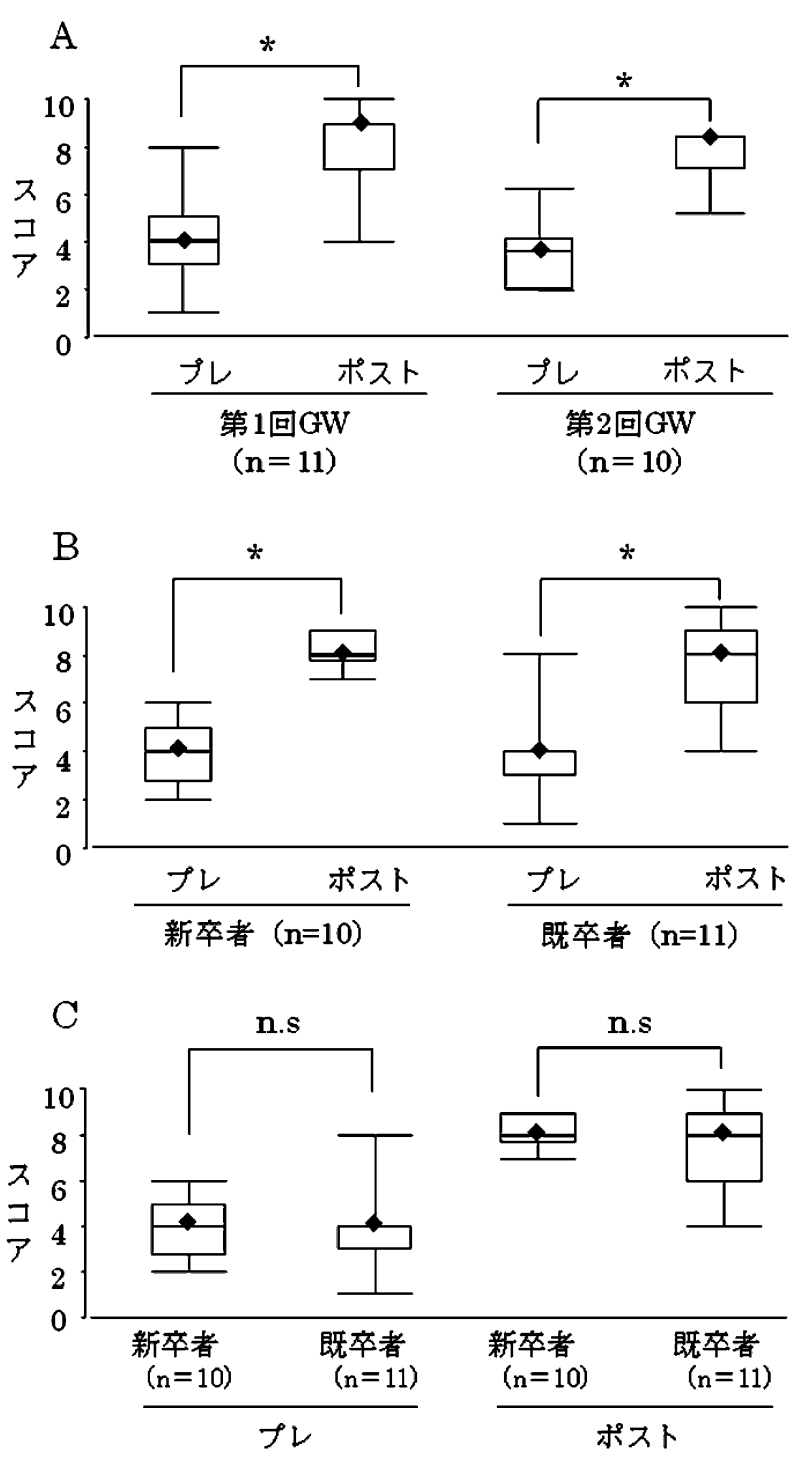

Fig. 5. Score of the Educational Evaluation Testing

A: Results of whole participants. B: Results of new graduates and former graduates. C: Difference between new graduates and former graduates. ${ }^{*} p$ $<0.01 v s$. pre test. $\diamond$ : median. The upper quartiles $=75 \%$. The lower quartiles $=25 \%$.

に対するスコアの中央值は，第 1 回 GW では 1 日 目 4.0，2 日目 3.0,第 2 回 GW では 1 日目 4.0, 2 日目 3.5 で，有意な差は認められなかった．問 2 に 対するスコアの中央值は, 第 1 回 GW では 1 日目
問1. 今日、あなたは討議にどの程度参加しましたか?
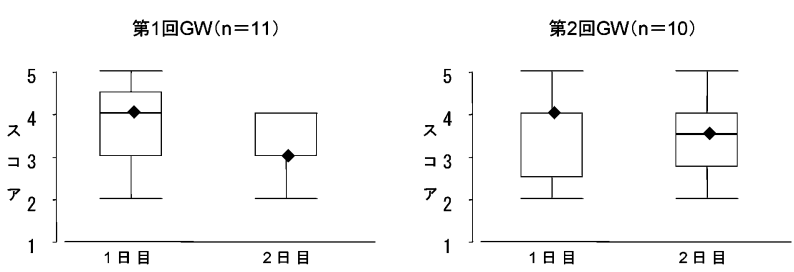

問2. 今日の内容は、あなたの期待に応えることができましたか?
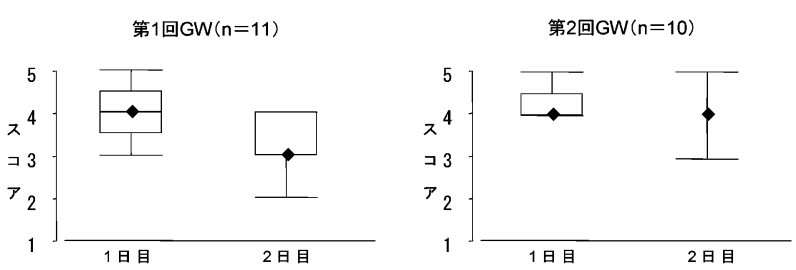

問3. 今日、あなたにとって価値ある変化がありましたか?
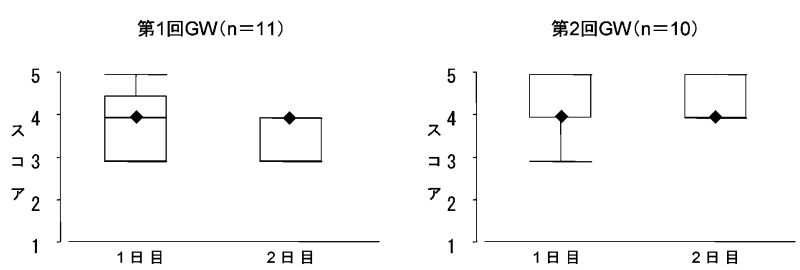

Fig. 6. Self-Evaluation after the Group Work

$\checkmark$ : median. The upper quartiles $=75 \%$. The lower quartiles $=25 \%$.

4.0, 2 日目 3.0, 第 2 回 GW では 1 日目 4.0, 2 日 目 4.0 で，有意な差は認められなかった。 問 3 に対 するスコアの中央值は，第 1 回 $\mathrm{GW}$ では 1 日目 4.0,

2 日目 4.0,第 2 回 GW では 1 日目 4.0, 2 日目 4.0 であった。

記述式の設問についての結果を Table 4 に示す. GW を通じて,「実習への不安が解消された」,「モ チベーションが上がった」という意見がみられた.

\section{考察}

今回われわれは，6年制の実務実習を受け入れる にあたり，実務経験の浅い薬剂師が効果的に実習指 導に係わることができる体制を構築するために, $\mathrm{GW}$ を開催し, コアカリのよりよい理解と実習指 導へのモチベーションの向上に対する有用性を検討 した。 $\mathrm{GW}$ は 2 日間で 4 時間程度の内容であった が, 教育評価演習の得点は有意に $(p<0.01)$ 上昇 した。また，新卒者と既卒者ともに得点は有意に $(p<0.01)$ 上昇した. このことより，今回のような $\mathrm{GW}$ は, 実務経験年数に関係なく, コアカリの理 
Table 4. Self-Evaluation after the Group Work

\begin{tabular}{|c|c|}
\hline 第 1 日 目 & 第 2 日 目 \\
\hline \multicolumn{2}{|l|}{ 今日, よく理解できたこと } \\
\hline $\begin{array}{l}\text { (1)6 年制の学生がどのように準備してくるかということ } \\
\text { (1)実習のネガティブなイメージをポジティブに変える方法 } \\
\text { (1)他の職員の実習に対する意識, 概念, 個々の思い } \\
\text { (1)コアカリの目標について } \\
\text { (1)(2実習における学生との係わり方, 教え方 } \\
\text { (2)教育とは価值ある変化をもたらすこと }\end{array}$ & $\begin{array}{l}\text { (1)(2)実習の具体的な流れがイメージできた } \\
\text { (1)学習方略や, 学生がどんなことを習得すべきなのか } \\
\text { (1)具体的な不安 } \\
\text { (2)価值ある変化を生むためにスケジュールを組む難しさ } \\
\text { (2)教育評価の意思決定が, 評価者, 学生の双方に関係してい } \\
\text { ることが具体的にわつた }\end{array}$ \\
\hline \multicolumn{2}{|l|}{ 今日, よく理解できなかつたこと } \\
\hline $\begin{array}{l}\text { (1)教えていることがコアカリに沿っているかどうか } \\
\text { (1)抽出した問題点の解決方法 } \\
\text { (1)(2)具体的に自分は何をしたらよいか } \\
\text { (2)学生のモチべーションを上げるために, 具体的にどうきっ } \\
\text { かけを作ってあげられるか }\end{array}$ & $\begin{array}{l}\text { (1)実際のスケジュール } \\
\text { (1)(2)評価方法. 誰が評価するのか } \\
\text { (1)(2)学生にどの程度教えたらよいのか } \\
\text { (2) どのレベルの薬剤師が, どの項目を担当するのか }\end{array}$ \\
\hline \multicolumn{2}{|l|}{ その他, 意見感想 } \\
\hline $\begin{array}{l}\text { (1)(2) } 1 \text { 年目でも教えられることがあるのだとわかった } \\
\text { (1)(2)実習に対してモチベーションが上がり, 満足の GW でし } \\
\text { た } \\
\text { (1)定期的にディスカッションを行うべき. 楽しい } \\
\text { (1)とても勉強になる GW で, 不安が少し解消された } \\
\text { (1)(2)教えることに不安があったが, 学生に考えさせることが } \\
\text { 大事だとわかつた } \\
\text { (1)次は, 問題点への対策を考えないといけないと思う }\end{array}$ & $\begin{array}{l}\text { (1)(2)自分も実習に参加するという実感がわいた } \\
\text { (1)実習に対してネガティブなイメージあったが, ポジティ } \\
\text { ブに捉えていううです } \\
\text { (2)学生や自分に価値ある変化を生み出すためのよい勉強にな } \\
\text { つた } \\
\text { (1)(2)教えることは自分の知識定着のためにもなるので, 実習 } \\
\text { までにもつと勉強して, 実習に係わつていきたい } \\
\text { (2)具体的な実習の流れについて有意義な討論ができた } \\
\text { (1)SGD のポイント, 作業方法がわかり難かつた }\end{array}$ \\
\hline
\end{tabular}

(1)は第 1 回 GW, (2)は第 2 回 GW を示す.

解に有用な方法であることが示唆された，GW 前 後に実施したアンケートにおいて，GW 後では参 加者の $90 \%$ 以上が，今後実習に「積極的に係わり たい」又は「係わりたい」と回答した.これらのこ とから，本 GW は，モチベーション向上に有用で あり，実習指導体制構築の一助となる優れたモデル であると考える。

教育評価演習の結果から，参加者はコアカリに対 する事前の認識にかかわらず, $\mathrm{GW}$ 参加により有 意な知識の向上を認めた。このことは，鈴木ら5)の 報告と同様に，プレ教育評価演習が，自分の知識の 足りない部分を認識し, 自らレクチャーで学ぶべき ポイントを見い出し，集中して知識の習得に取り組 むことができた結果と考える.

実務経験の浅い薬剂師が実習指導に直接係わるこ とは，学生にとって身近なロールモデルとして実習 に係わることができ，早い段階から正しい知識と実 習指導への姿勢を身に付けておくことこそが，将来 の指導薬剤師としてともに育つ実習を行うために有 効な手段であると考える。 山本ら ${ }^{1)}$ は，長期実務実
習においても認定実務実習指導薬剤師など経験豊富 な薬剤師の適切な管理の下であれば，新人薬剤師に よる薬学生への指導は可能であると述べている．ま た, 薬学生・新人薬剂師の相互教育効果のみなら ず，人員不足や指導者の負担軽減の一助にもなり得 ると考えている，今後は，6 年制課程を卒業した薬 剂師が指導薬剂師とともに実習指導に携わる機会を 想定した実習指導体制の構築が必要となる.

永田6) は，事前準備を適切に遂行するには，受け 入れ施設の職員が協力しあうことが不可欠であると している。 しかし，実習カリキュラムについての教 育を受けていない職員には, 教育用語は理解し難 く, 必然的に指導薬剂師のみに立案を任せている場 合が多いと指摘している。また，薬局全体のモチ ベーションを上げるために，事前準備に協力してく れる仲間を増やす対策を講じる必要があるとしてい る.このことからも，本 $\mathrm{GW}$ は，職員個々のコア カリに対する理解度及び実習指導に対するモチベー ションを向上させることができ，実習指導体制を構 築するうえで意義ある取り組みであったと考える. 
WS とは異なり, カリキュラムプランニングの手 法を体験することに留まらず，アクションプランの 実行に向けて，「実際に実習で使用するためのスケ ジュールを作成する」という目的を明確にして SGD を行ったことは, 参加者個々が能動的に立案 に係わることができ, 薬剤師数, 実務経験年数及び 業務形態の異なる施設においても同様の効果が期待 できる応用可能な方法であると考える. すなわち, 薬剂師数の少ない施設であっても, 地域の病院や保 険薬局が協力してグループ実習を展開し，協働で $\mathrm{GW}$ を開催することにより, 実現可能な方法であ ると考える。また，本 GW において第 2 回 GW で は実務経験者と新卒者に分かれて SGD を行った。 その結果, 新卒者は, 自身の実習及び就職後の経験 を基に, 学生に近い立場で問題点を抽出し, 作成し た方略が SBOs 達成のために効果的な方法であるか どうか評価しながら議論することができた。このこ とより, 実務経験年数の分布に応じてグループ分け を工夫することも, 効果的な $\mathrm{GW}$ 開催の要因の 1 つになると考えられる.

GW 前後に行ったアンケート結果 (Fig. 4) から, GW 後では全員が, 実習指導は自分にとって意味 があると回答したことから，実習指導への意識の高 さが窥えた。ささらに，この結果を既卒者と新卒者に 分けて比較してみると, 新卒者のほうが, $\mathrm{GW}$ 後 実習指導は自分にとって意味があると思うかの設問 に，「とてもそう思う」と回答した割合が高い傾向 を示した. このことから, 今回のような $\mathrm{GW}$ を就 職後早い段階から体験することで, 実習指導へのモ チベーション向上につながることが示唆された．ま た，プレアンケートでは，6 割以上が「人に教える ことは苦手」と回答していたが, GW 参加により 実習指導へ積極的に関与したいという意識が上昇し たことが示された．これらのことから，GWへの 参加は，人に教えることに対する苦手意識の克服に も有効であったと考えられる。第 1 回 GW と比較 して第 2 回 $\mathrm{GW}$ 参加者は, プレアンケートの段階 で実習指導に対する意識が高かった (Fig. 4)。こ の要因の 1 つとして, 第 2 回 $\mathrm{GW}$ の開催が実習受 け入れ直前であったことが影響していると考えられ る.また, 第 2 回 GW では,「積極的に係わりたい」 の回答が $40 \%$ から $70 \%$ 上昇したことから，GW は事前にモチベーションが高い場合でも, さらにモ
チベーションを向上させることができる方法である ことが示唆された。

自己評価の結果（Fig. 6）から，1 日目と 2 日目 で有意な差は認められず，参加者は 2 日間を通して 一定の価值ある変化を感じていた。 また, 記述回答 (Table 4) から分かるように, 実習への不安が解消 され，実習指導へのモチベーションが向上したこと を示す複数の意見が得られたことから $\mathrm{GW}$ 開催の 有用性が示された。特に実務経験が浅い薬剤師から は，「実習の具体的流れがイメージできた」，「1年 目でも教えられることがあるのだとわかつた」など, $\mathrm{GW}$ への参加を通じて, 長期実務実習の全容や個 々の役割を明確にすることができたことを示唆する 意見が得られた。また，第 2 回 GW 後，実習開始 までに，解決策が必要と考えられる内容 (Table 1) を基に，SBOsに対応した「調剂室実習指導支援 シート」を作成し, 指導内容の均一化を図った。

GW を通じて参加者それぞれが価值ある変化を感 じることで, SGDの必要性や有用性を見い出すこ とができていた。このことは，一時的な効果だけで なく, 実習開始後の定期的な $\mathrm{GW}$ 開催の原動力と なったと考えられる.

今回の報告では, 実習受け入れの事前準備とし て, コアカリの理解と指導者のモチベーション向上 に，GW 開催が有用であることを明らかにした。 引き続きわれわれは，I期， II 期， III期の各実習後 に GW を開催し, 実習指導の問題点抽出と, 問題 点に対する次期実習への対応策を検討することで, 自らのモチベーション維持と質の担保に取り組んで いるところである. 今後も, より質の高い実習指導 体制の構築に向けて，このような取り組みが全国の 施設に広がり，人員不足や指導者の負担軽減に有効 活用されるよう取り組んでいきたい。

\section{REFERENCES}

1) Yamamoto T., Washiyama A., Sejima E., Shibaguchi H., Kataoka Y., Futagami K., Yakugaku Zasshi, 130, 821-831 (2010) .

2) Okunomiya T., Morimoto T., Nakajima T., Ogura T., Hiraide A., Medical Education (Japan), 40, 65-71 (2009).

3) Mochizuki M., Gekkan Yakuji, 52, 171-173 (2010).

4) Yamamoto T., Washiyama A., Inokuchi H., 
Siotuka S., Fujikane H., Ikeuti T., Kawahara Y., Futagami K., Jpn. J. Pharm. Health Care Sci., 35, 752-761 (2009).

5) Suzuki R., Fujimoto T., Matsumoto K., Med- ical Education (Japan), 31, 473-476 (2000) .

6) Nagata T., Gekkan Yakuji, 52, 219-223 (2010) . 